\title{
Formation of nanocrystals based on equimolar mixture of lanthanum and yttrium orthophosphates under microwave-assisted hydrothermal synthesis
}

\author{
M. O. Enikeeva ${ }^{1,2}$, O. V. Proskurina ${ }^{1,2}$, D. P. Danilovich ${ }^{2}$, V. V. Gusarov ${ }^{1}$ \\ ${ }^{1}$ Saint Petersburg State Institute of Technology, Moskovsky Pr., 26, Saint Petersburg, 190013, Russia \\ ${ }^{2}$ Ioffe Institute, Politekhnicheskaya St. 26, Saint Petersburg, 194021, Russia \\ odin2tri45678@gmail.com,proskurinaov@mail.ru,dmitrydanilovich@gmail.com,victor.v.gusarov@gmail.com
}

DOI 10.17586/2220-8054-2020-11-6-705-715

\begin{abstract}
The effect of hydrothermal-microwave treatment time at $180^{\circ} \mathrm{C}$ on the phase composition, dimensional parameters of crystallites and nanoparticles of solid solutions of lanthanum and yttrium orthophosphates in the system $0.53 \mathrm{LaPO}_{4}-0.47 \mathrm{YPO}_{4}-\left(n \mathrm{H}_{2} \mathrm{O}\right)$ has been determined. It has been proposed the mechanism for structural transition of lanthanum-yttrium orthophosphate solid solution with rhabdophane structure into monazite structure, which consists in the degeneration of nanocrystals having rhabdophane structure along certain edges into monazite structure. It is shown that phase nanoparticles of monazite structure having average crystallite size of 15-17 nm begin to form after 30 minutes of hydrothermalmicrowave treatment at $180^{\circ} \mathrm{C}$ immediately after complete crystallization of amorphous phase in the system. The nanoparticle size increase (length of nanorods) with monazite structure after the stage of their formation occurs, mainly due to matter transfer from nanoparticles having rhabdophane structure to nanoparticles having monazite structure. In this case, the system considered conditions of hydrothermal treatment (temperature $180{ }^{\circ} \mathrm{C}$, pressure $\sim 1-1.5 \mathrm{MPa}$, duration - up to $120 \mathrm{~min}$ ) remains two-phase.
\end{abstract}

Keywords: nanocrystals, lanthanum and yttrium orthophosphates, monazite, rhabdophane, hydrothermal treatment, microwave heating, phase transition.

Received: 28 August 2020

\section{Introduction}

Much attention to the study of formation processes, structure and properties of materials, including nanocrystalline materials, based on orthophosphates of rare earth elements is associated with set of practically important properties that they possess. Ceramic materials based on rare earth element (REE) orthophosphates due to their high strength, thermal stability and resistance to aggressive media are used as high-temperature insulation [1-3]. They have a high isomorphic capacity for large number of lanthanides and actinides [4-7], are resistant to radiation damage [8], which makes them promising as ceramic matrices for radioactive waste immobilization. Among the numerous REE orthophosphates, two- and multicomponent phases $[9,10]$ are of considerable interest. They have applicability as structural [11] and luminescent materials [12,13], thermal barrier coatings [14], as proton-conducting electrolyte [15-18]. Lanthanum orthophosphate is used as component of two-phase mixtures with refractory oxides to produce reinforced high-temperature ceramics [19].

A number of papers [20-26] have shown that some properties of materials change significantly in cases when the crystal size is of the nanoscale region. This behavior pattern of nanocrystalline materials also applies to REE orthophosphates [27-31]. In this regard, it is interesting, particularly, to study the processes of phase formation, structural transformations and physicochemical properties of nanocrystalline solid solutions in the system $\mathrm{LaPO}_{4}-\mathrm{YPO}_{4}-$ $\left(\mathrm{H}_{2} \mathrm{O}\right)$. Phase formation and their properties in this system were considered in [5,32-35], however, the discrepancies in obtained results make it relevant to continue such studies.

To obtain multicomponent nanocrystalline orthophosphates, methods of soft chemistry are successfully applied, such as precipitation [36], sol-gel [37,38], microreactor synthesis [39], hydrothermal [40-43] and hydrothermal microwave-assisted synthesis [43-45]. Hydrothermal conditions make it possible to obtain nanocrystalline particles with different structures and morphologies by varying the $\mathrm{pH}$, treatment time and temperature of synthesis $[9,10,46,47]$. One of the advantages for microwave-assisted synthesis is the rapid heating of reaction medium. This feature, along with possibility of sensitive control of temperature and treatment time, is important for studying the kinetics of nanocrystalline particles formation [43].

This paper is aimed at studying processes of formation and structural transformations under microwave-assisted conditions of nanocrystalline solid solutions based on lanthanum-yttrium orthophosphates in the system $0.5 \mathrm{LaPO}_{4}-$ $0.5 \mathrm{YPO}_{4}-\left(n \mathrm{H}_{2} \mathrm{O}\right)$. The article discusses the effect of isothermal holding time on formation and change in dimensional parameters of nanocrystals of lanthanum-yttrium orthophosphates with rhabdophane and monazite structures. 


\section{Experimental}

Nanocrystalline samples of solid solutions of lanthanum-yttrium orthophosphates in the system $\mathrm{LaPO}_{4}-\mathrm{YPO}_{4}-$ $\left(\mathrm{H}_{2} \mathrm{O}\right)$ were synthesized in an Anton Paar Monowave 400 hydrothermal microwave reactor. Equimolar solutions of lanthanum nitrate hexahydrate (C.P.), yttrium nitrate pentahydrate (C.P.) and ammonium dihydrogen phosphate (C.P.) were used as mother substances. The ammonium phosphate solution was added at constant stirring for 10 minutes to water solution of premixed lanthanum and yttrium nitrates with $\mathrm{pH}=1$. The ratio of reagent solutions was selected to ensure the pre-set stoichiometry of products. The resulting suspension was transferred into glass autoclave flask of microwave reactor (the fill factor 0.3). The daughter of reaction was stirred at $600 \mathrm{rpm}$ during the whole treatment time. The reactive atmosphere treated at $180{ }^{\circ} \mathrm{C}$ and was recorded inside the autoclave using the ruby thermometer. The pressure into autoclave flask was about 1-1.5 MPa. The reactive atmosphere was heated to pre-set temperature for 1 minute, the isothermal holding time from 5 up to 120 minutes, followed by cooling to $70{ }^{\circ} \mathrm{C}$ for 8 minutes. Treatment products were precipitated by centrifugation, washed several times with distilled water, and dried at $80{ }^{\circ} \mathrm{C}$.

The elemental composition of the samples was determined by EDAX attachment for X-ray spectral microanalysis for FEI Quanta 200 scanning electron microscope (SEM) having composition determination error was about $2 \%$.

Powder X-ray diffraction patterns were taken with a Rigaku SmartLab 3 X-ray diffractometer The X-ray $\left(\mathrm{Cu}_{K \alpha}\right.$ radiation) within the angle range $2 \theta=10-65^{\circ} \mathrm{C}$ with an $0.01{ }^{\circ} \mathrm{C}$ step at a scanning speed $1{ }^{\circ} \mathrm{C} / \mathrm{min}$. Qualitative $\mathrm{X}$-ray diffraction analysis was carried out using the PDF- 2 database. The rhabdophane and monazite phase ratio in these samples was calculated according to the peaks that did not overlap in the pahse mixture: the characteristic peak for rhabdophane is (100), and for monazite - (200). The X-ray amorphous phase portion was determined using corundum as the internal standard. The average crystallite sizes, as well as lognormal size distributions, were defined using the SmartLab Studio II software by Rigaku according to the specified reflexes.

Sample micrographs and electron microdiffraction data were obtained using the JEOL JEM-2100F transmission electron microscope at accelerating voltage $200 \mathrm{kV}$. The images were processed using the ImageJ program. The particle size were determined were determined from the data on approximately 100 separate particles for each sample.

\section{Results and discussion}

Elemental analysis of samples shows that the ratio of elements La:Y is 53:47 ( $\pm 1-2 \%)$ atm \%, the ratio of elements $(\mathrm{La}+\mathrm{Y}): \mathrm{P}$ is 51:49 $( \pm 2 \%)$ at.\%, corresponding within the analysis uncertainty to the ratio set by synthesis $\mathrm{LaPO}_{4}: \mathrm{YPO}_{4}=0.5: 0.5$.

The X-ray diffraction data (Fig. 1) show that in as-precipitated sample, before the hydrothermal microwaveassisted treatment, are presented rhabdophane reflexes.

Figure 2 shows data on quantitative phase ratio in the system depending on the isothermal holding time during hydrothermal-microwave treatment at $180^{\circ} \mathrm{C}$. It should be pointed out that the sample contains $\sim 30 \%$ of amorphous phase before the heating treatment.

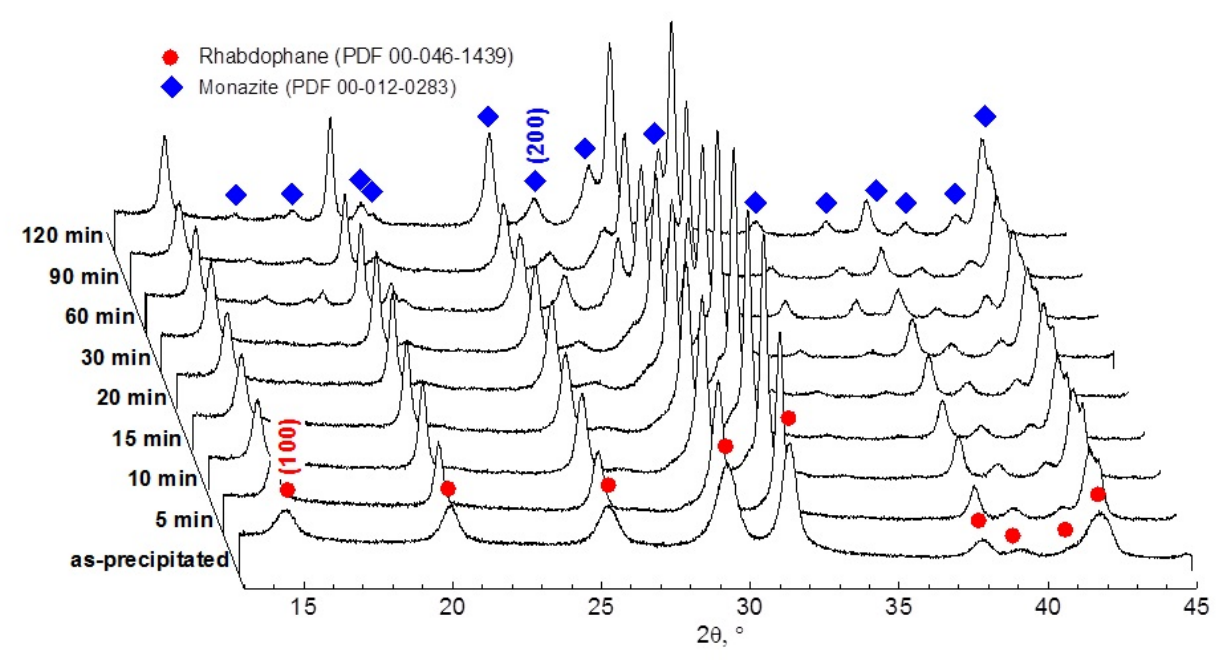

FIG. 1. The X-ray diffraction pattern of samples before and after hydrothermal-microwave treatment at $180{ }^{\circ} \mathrm{C}$ 
After hydrothermal treatment for 20 minutes, the X-ray amorphous phase completely disappears, the sample is contented solely by the phase with rhabdophane structure. Taking into account the lack of other phases and the ratio of elements in the system due to the analysis data $-0.53 \mathrm{LaPO}_{4}-0.47 \mathrm{YPO}_{4}-\left(n \mathrm{H}_{2} \mathrm{O}\right)$, it can be concluded after microwave hydrothermal treatment at $180{ }^{\circ} \mathrm{C}$ and under a pressure of $1-1.5 \mathrm{MPa}$ for $20 \mathrm{~min}$, the solid solution is formed with the averaged composition $\mathrm{La}_{0.53} \mathrm{Y}_{0.47} \mathrm{PO}_{4}\left(n \mathrm{H}_{2} \mathrm{O}\right)$. Isothermal holding under hydrothermal conditions at $180{ }^{\circ} \mathrm{C}$ for $30 \mathrm{~min}$ leads to the occurrence of phase with monazite structure (Fig. 1, 2). It is worth noting that for all samples in the studied system, $0.5 \mathrm{LaPO}_{4}-0.5 \mathrm{YPO}_{4}-\left(n \mathrm{H}_{2} \mathrm{O}\right)$ do not complete the transition of the rhabdophane phase into monazite. Phase ratio in samples with isothermal holding from 60 up to $120 \mathrm{~min}$ almost does not change (phase with monazite structure): (phase with rhabdophane structure) $\approx 70: 30( \pm 5 \%) \mathrm{wt} \%$ (Fig. 2). Thus it is impossible $a$ priori to state that the transformation of the solid solution with rhabdophane into monazite structure occurs without composition change. The complexity of determining the elemental composition of individual nanoparticles in twophase composition does not allow one to answer the question of the phase composition coexisting in the system by their direct elemental analysis. In such cases, the necessary information can be given by the correlation between the composition and parameters of the lattice constants.

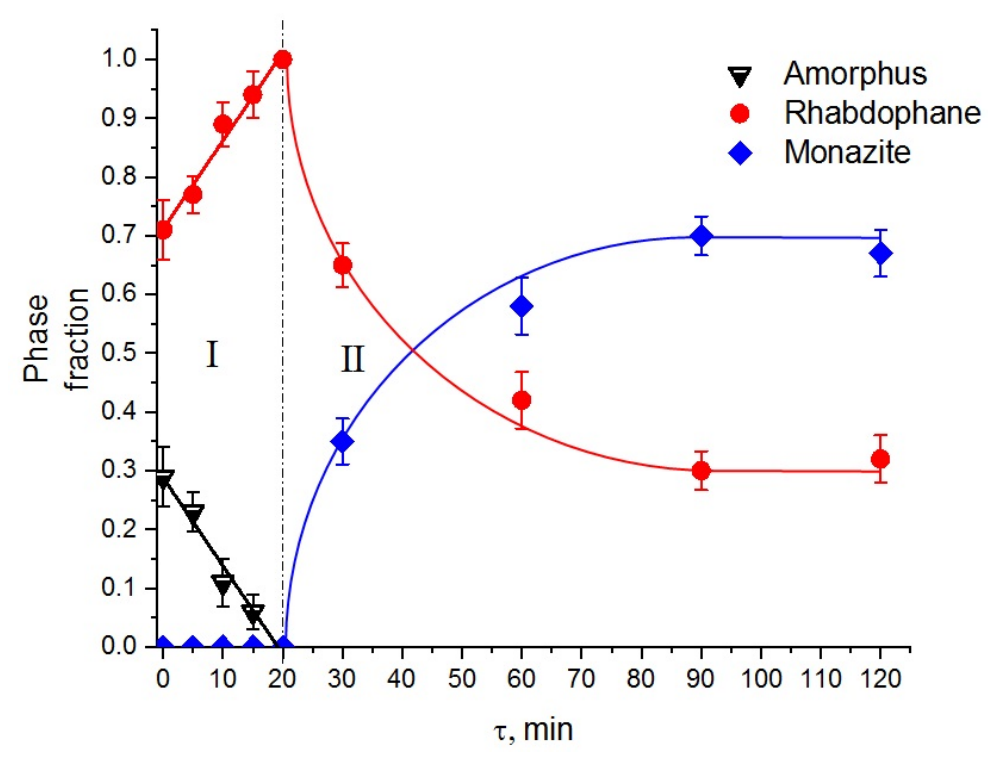

FIG. 2. The phase ratio depending on the isothermal holding time under hydrothermal microwaveassisted conditions at $180^{\circ} \mathrm{C}$

The available literature data on the of elementary cells volume of solid solutions $\mathrm{La}_{1-x} \mathrm{Y}_{x} \mathrm{PO}_{4}$ with monazite structure and solid solutions $\mathrm{La}_{1-x} \mathrm{Y}_{x} \mathrm{PO}_{4}\left(n \mathrm{H}_{2} \mathrm{O}\right)$ with rhabdophane structure are represented in Fig. 3. According to prior research on the dependence of the elementary cell volume of phase with monazite structure on the composition of the $\mathrm{La}_{1-x} \mathrm{Y}_{x} \mathrm{PO}_{4}$ solid solution significantly differ from the data of other papers, further analysis was carried out without taking into account the results of this paper [35]. The data of this work on the elementary cell volume of monazite structure led us to conclude that the composition of the solid solution corresponds to the values $x \approx 0.25-$ 0.28 . The hydrothermal treatment time increase results in slight increase values $x-$ from $\sim 0.25$ to 0.28 . It is much more difficult to draw any quantitative conclusions about the lanthanum and yttrium ratio change in the solid solution with rhabdophane structure during the structural transformation process, since the unit cell volume of phase with rhabdophane structure depends upon, to a large extent, the water content in the structure. Particularly, this is reflected in large fluctuations in the volume of the unit cell, in depending on the synthesis conditions (Fig. 3). However, the data from this research shows that that with an increase in the duration of hydrothermal treatment, the unit cell volume of the solid solution with a rhabdophane structure systematically and significantly decrease (Fig. 3), as may be a consequence of an increase in the content of yttrium orthophosphate in it. Overall it compensates for the precipitation of the solid solution with a monazite structure enriched with lanthanum orthophosphate in comparison with the initial composition of the system. In such a way, the analysis carried out allows one to conclude the transition of the solid solution $\mathrm{La}_{1-x} \mathrm{Y}_{x} \mathrm{PO}_{4}\left(n \mathrm{H}_{2} \mathrm{O}\right)$ the rhabdophane structure into monazite structure leads to a phase composition change. There can be an explanation for the simultaneous coexistence in two systems of phases observed in this experiment, that is to say, under hydrothermal conditions at the temperature of $180{ }^{\circ} \mathrm{C}$ and a pressure of $\sim 1-1.5 \mathrm{MPa}^{\text {in }}$ the $\mathrm{LaPO}_{4}-$ $\mathrm{YPO}_{4}-\left(\mathrm{H}_{2} \mathrm{O}\right)$ system in the range of $\mathrm{LaPO}_{4}: \mathrm{YPO}_{4}=0.53: 0.47$. There exists a solid solution with a monazite structure 


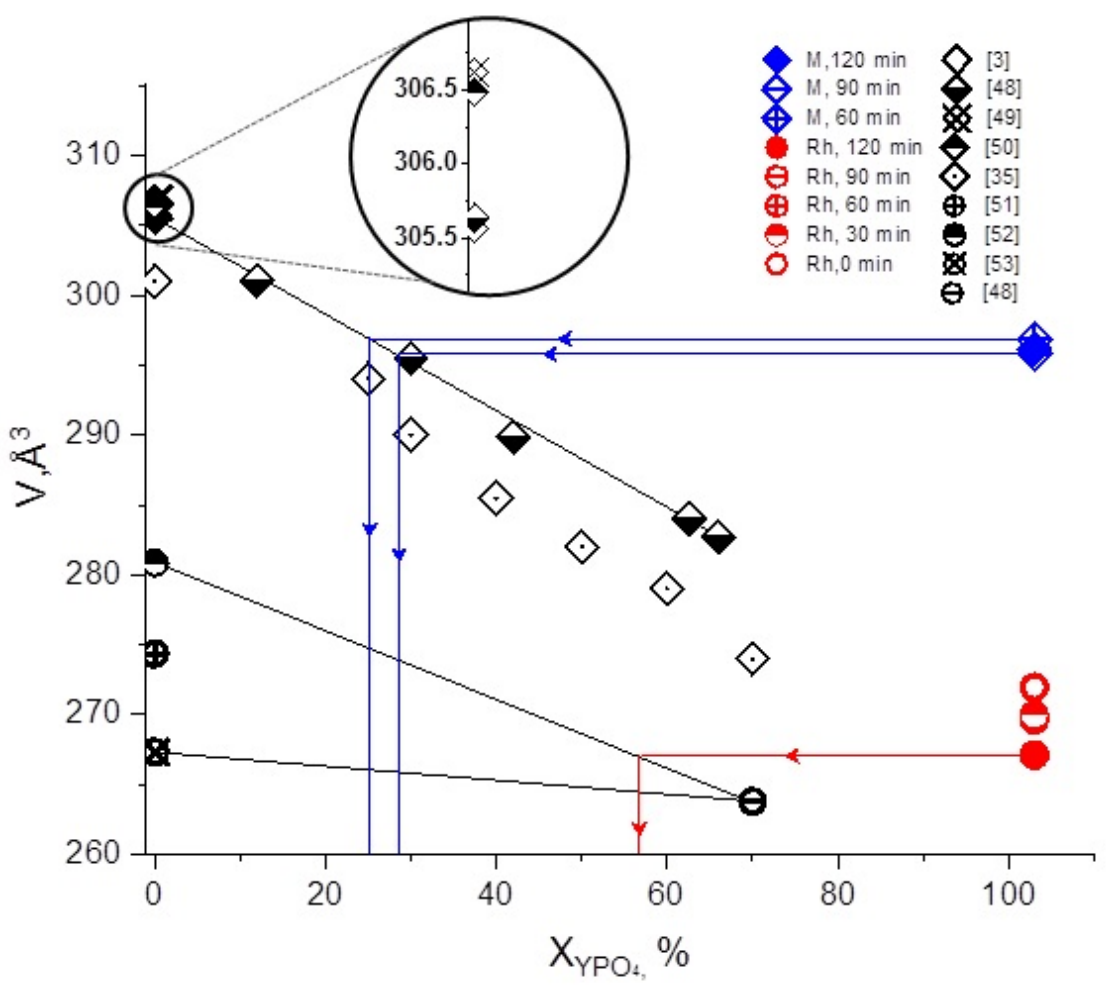

FIG. 3. Unit cell volume of phases of variable composition with the structure of rhabdophane and monazite

of the composition $\mathrm{La}_{1-x} \mathrm{Y}_{x} \mathrm{PO}_{4}$, where $x \approx 0.25-0.28$, and another solid solution with the structure of rhabdophane $\mathrm{La}_{1-y} \mathrm{Y}_{y} \mathrm{PO}_{4}\left(n \mathrm{H}_{2} \mathrm{O}\right)$, where $y>0.47(\sim 0.57)$.

The dependence of crystallite sizes of solid solutions of lanthanum-yttrium orthophosphates with rhabdophane and monazite structure, determined from non-overlapping reflections (100) and (200), respectively, on the isothermal holding time is shown in Fig. 4. The size distribution of crystallites determined from the same reflexes is shown in Fig. 5. From the analysis of the data presented in Fig. 4, it follows that with an increase holding time from 0 to 20 minutes, the average crystallite size of solid solutions with rhabdophane structure increases from $\sim 10$ to $\sim 22 \mathrm{~nm}$.

The size distribution of crystallites of the solid solution with rhabdophane structure for sample with the isothermal holding for 20 minutes becomes wider (Fig. 5). The existence of the solid solution of lanthanum-yttrium orthophosphate with monazite structure in the sample after 30 minutes leads to the narrow size distribution (Fig. 5) with the subsequent growth of crystallites to $26 \mathrm{~nm}$ (and distribution width) for sample with isothermal holding for $120 \mathrm{~min}$ utes, which is consistent with the data [43].

Crystallites of solid solutions of lanthanum-yttrium orthophosphates with monazite structure, formed after 30 min of isothermal holding, have the average size of about $14 \mathrm{~nm}$, and for longer period, the average crystallite size, determined by the (200) reflection, stabilizes at level of $\sim 18 \mathrm{~nm}$ (Fig. 4). Size distribution of crystallites of solid solution with monazite structure as the isothermal holding time increases from 60 to 120 minutes does not undergo any significant changes (Fig. 5). However, it should be noted that these results were formulated based on the X-ray data for only one non-overlapping reflex (200).

TEM data analysis shows that the particles of the solid solution of lanthanum-yttrium orthophosphate with rhabdophane structure within the occurrence of single crystalline phase (after hydrothermal treatment for 20 minutes) have characteristic shape of short rods with average thickness of 20-30 nm and length range of $\sim 25-100 \mathrm{~nm}$ (Fig. 6a). Rhabdophane nanoparticles of the same morphology also can be found in TEM images of samples after hydrothermal treatment with isothermal holding at 30 and 120 minute (Fig. 6c,e), even if, the monazite phase appears in significant quantities according to X-ray diffraction data. At the same time, in the samples after hydrothermal treatment at 30 and 120 minutes, when the monazite phase is present, there occurs in the samples (Fig. 1,2), long and thin nanorods which are clearly visible, which can be reliably correlated with the monazite phase structure according by electron 


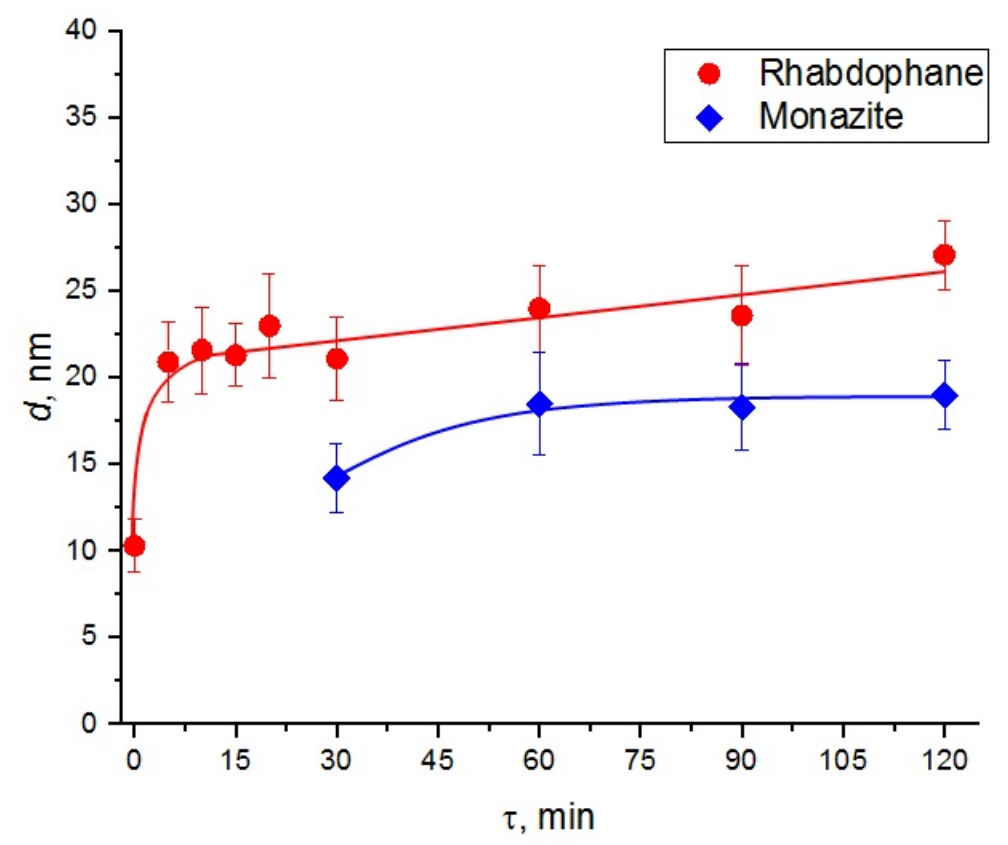

FIG. 4. Average crystallite size (according to reflex (100) - rhabdophane structure, and according to reflex (200) - monazite structure)

microdiffraction data. Fig. 6b,d,f show interplanar distances corresponding to phases with rhabdophane and monazite structures, as well as electron microdiffraction data, showing available crystalline phases with rhabdophane and monazite structures in the samples.

The size distribution of nanorod thickness and length is shown in Fig. 7. The determination of each particle belonging to the phases with rhabdophane and monazite was made according to their morphological features.

A bimodal type of thickness distribution of nanoparticles with rhabdophane structure phase for the sample after microwave-assisted treatment with isothermal holding at $180{ }^{\circ} \mathrm{C}$ for 20 minutes to a certain extent agrees with unusually wide crystallite size distribution data for this sample, which is not typical for other samples (Fig. 5). Apparently, the distribution of crystallites in this sample also has bimodal character, which cannot be determined within the framework of the existing possibilities of analyzing X-ray diffraction lines, based on the assumption about lognormal shape of the crystallite size distribution curve. It should be noted that the average thickness sizes of nanoparticles of this sample and the corresponding sizes of crystallites, determined from the reflection (100), are pretty close to each other. This allows us to conclude that nanorods of solid solutions of lanthanum-yttrium orthophosphate with rhabdophane structure at the stage of their formation are mainly represented by single-crystal particles. The bimodal size distribution of thickness of particles with rhabdophane structure for the sample after 20 minutes under hydrothermal conditions may be associated with the different nature of their formation when mixing reagents at room temperature and during the amorphous phase crystallization under hydrothermal conditions. Nanoparticles with rhabdophane structure having greater thickness remain in the sample after hydrothermal treatment for 30 minutes, while thinner particles are transformed into particles with monazite structure. After transformation of some particles with rhabdophane structure into monazite structure - after $30 \mathrm{~min}$ of isothermal holding, the rhabdophane particle thickness distribution becomes unimodal (Fig. 7c), which correlates with the crystallite size distribution narrowing data for this sample (Fig. 5). The average length of particles with rhabdophane structure more than doubles during the hydrothermal treatment process: from $\sim 37$ to $\sim 83 \mathrm{~nm}$. The occurrence in the sample after prolonged hydrothermal treatment (120 minutes) of wide, close to uniform thickness distribution of particles with rhabdophane structure at interval of particle size variation of $\sim 20-55 \mathrm{~nm}$ can be associated with coalescence of particles of solid solutions of lanthanum-yttrium orthophosphates, for example, by the aggregation-accommodation mechanism [48]. It should be noted that coalescence of nanorods with rhabdophane structure in fluent media is characteristic for these nanoparticles [39]. This pattern of nanoparticle thicknesss increasing is confirmed by comparison of the TEM data with the data on the crystallite sizes of these particles, which shows that their average values after prolonged hydrothermal treatment remain at level of $\sim 25 \mathrm{~nm}$.

Figure $6 \mathrm{~d}$ shows conjugated nanorods of monazite phase and rhabdophane phase. The rhabdophane phases are attached to the planes corresponding to the elementary cell parameter $c=6.37 \AA$, at angle of $40{ }^{\circ} \mathrm{C}$ to the (101) plane of monazite phases (at interplanar distance $4.1 \AA$ ). 

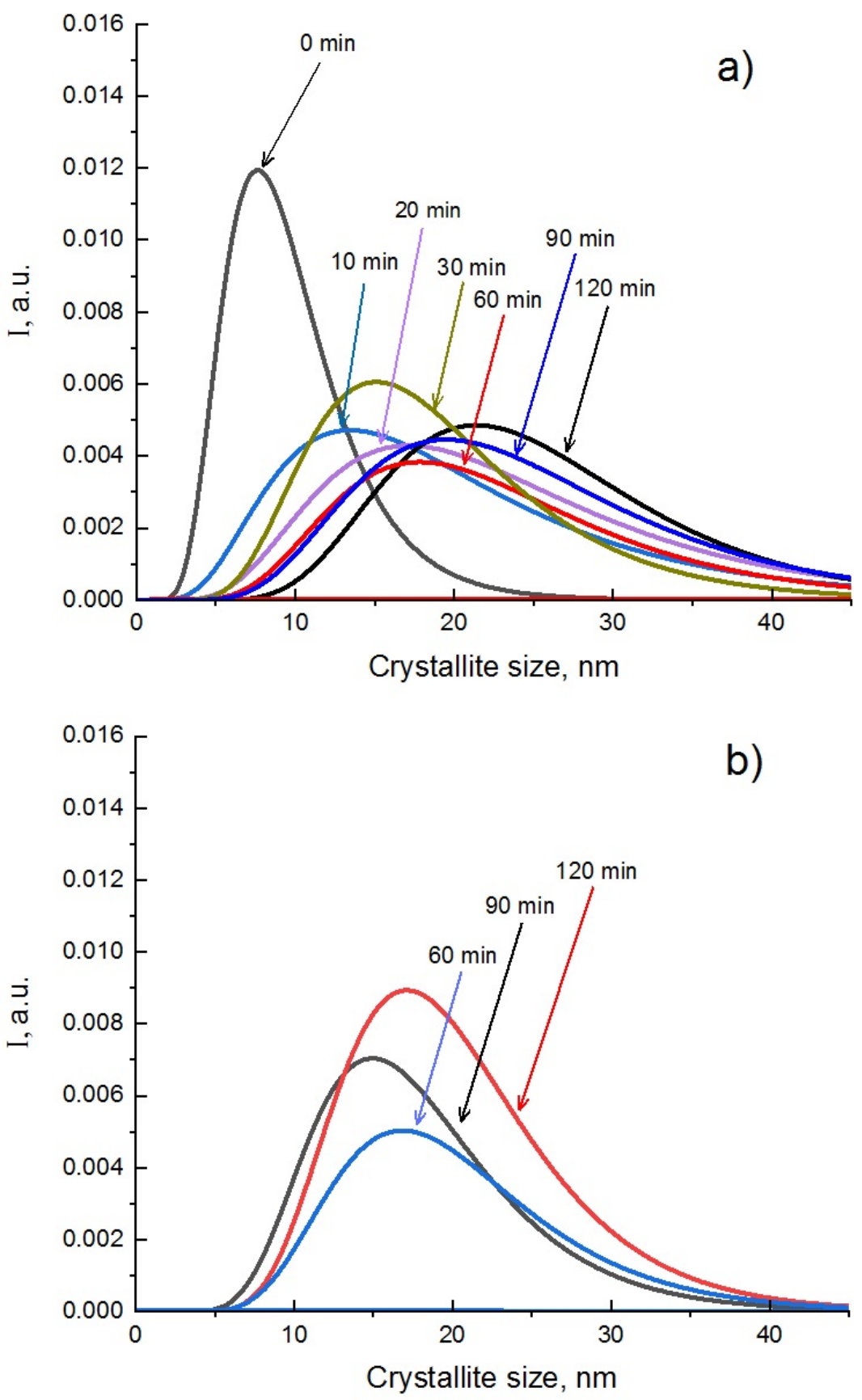

FIG. 5. Size distribution of crystallites of solid solutions of lanthanum-yttrium orthophosphates with rhabdophane (a) and monazite (b) 

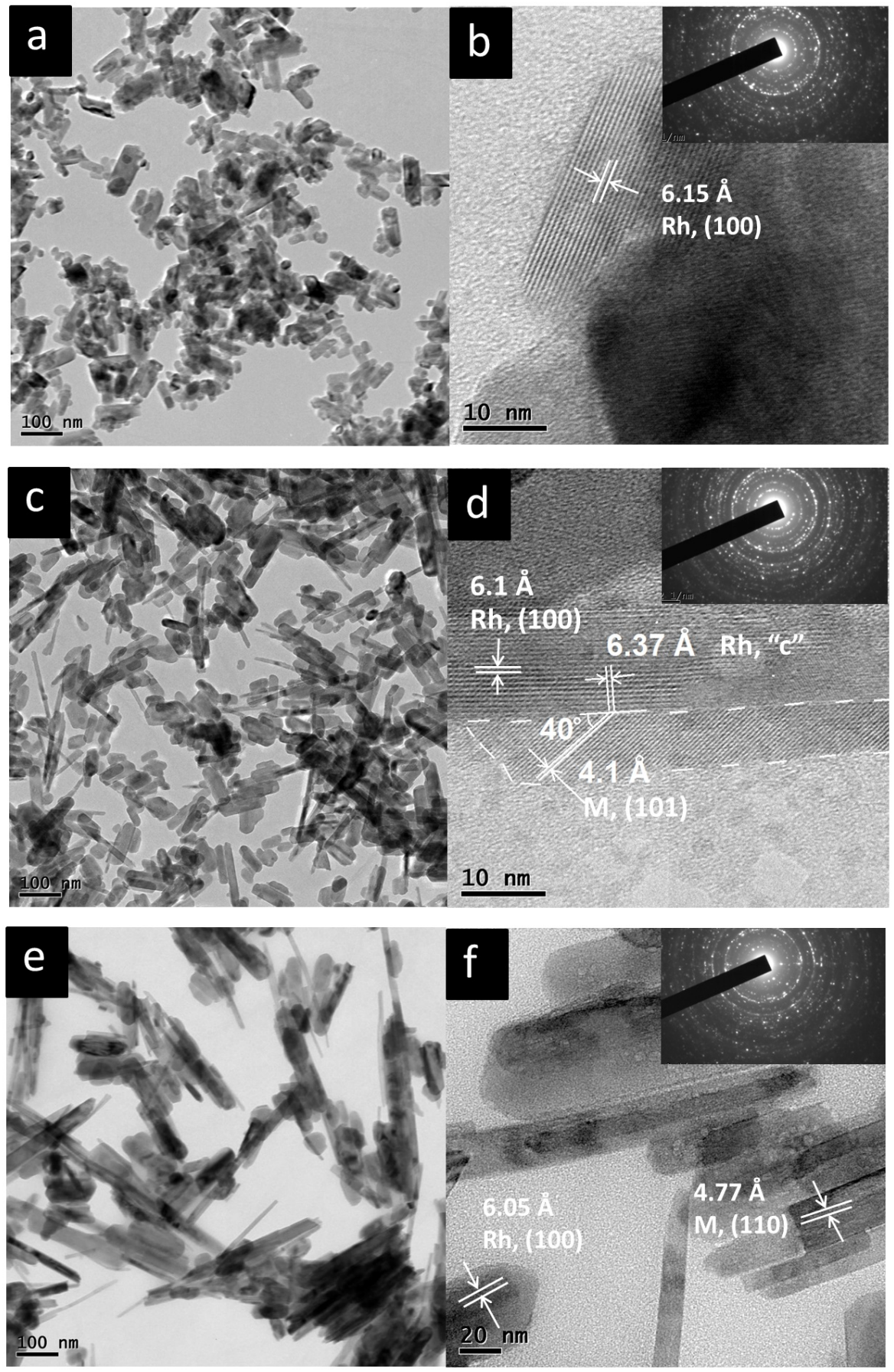

FIG. 6. Fig. 6. TEM micrographs of samples after hydrothermal treatment with isothermal holding at $180{ }^{\circ} \mathrm{C}$ for various durations: $(\mathrm{a}, \mathrm{b})-20$ minutes; (c,d) -30 minutes; $(\mathrm{e}, \mathrm{f})-120$ minutes. The rhabdophane phase is designated as $\mathrm{Rh}$, the monazite phase as $\mathrm{M}$ 

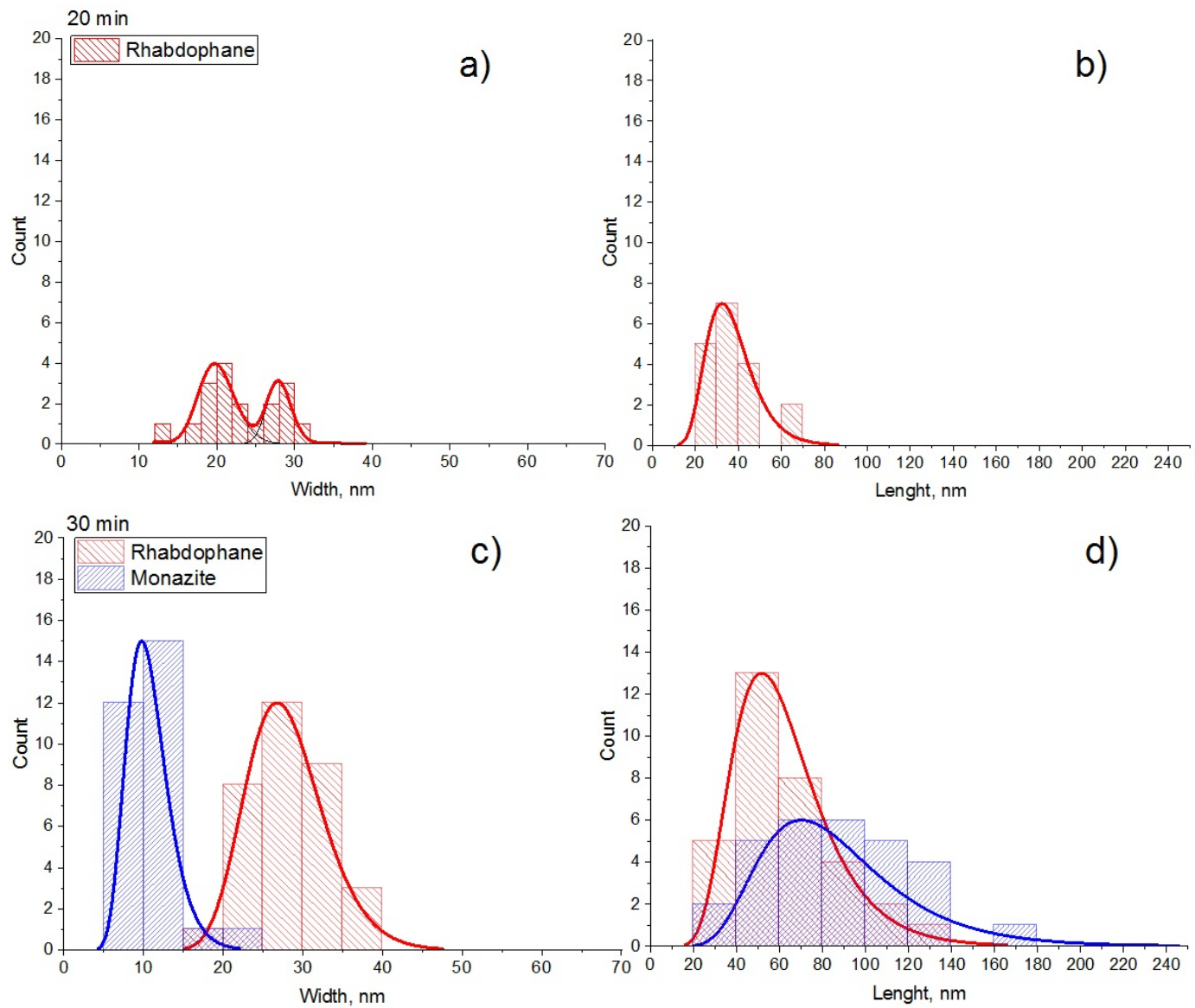

C)
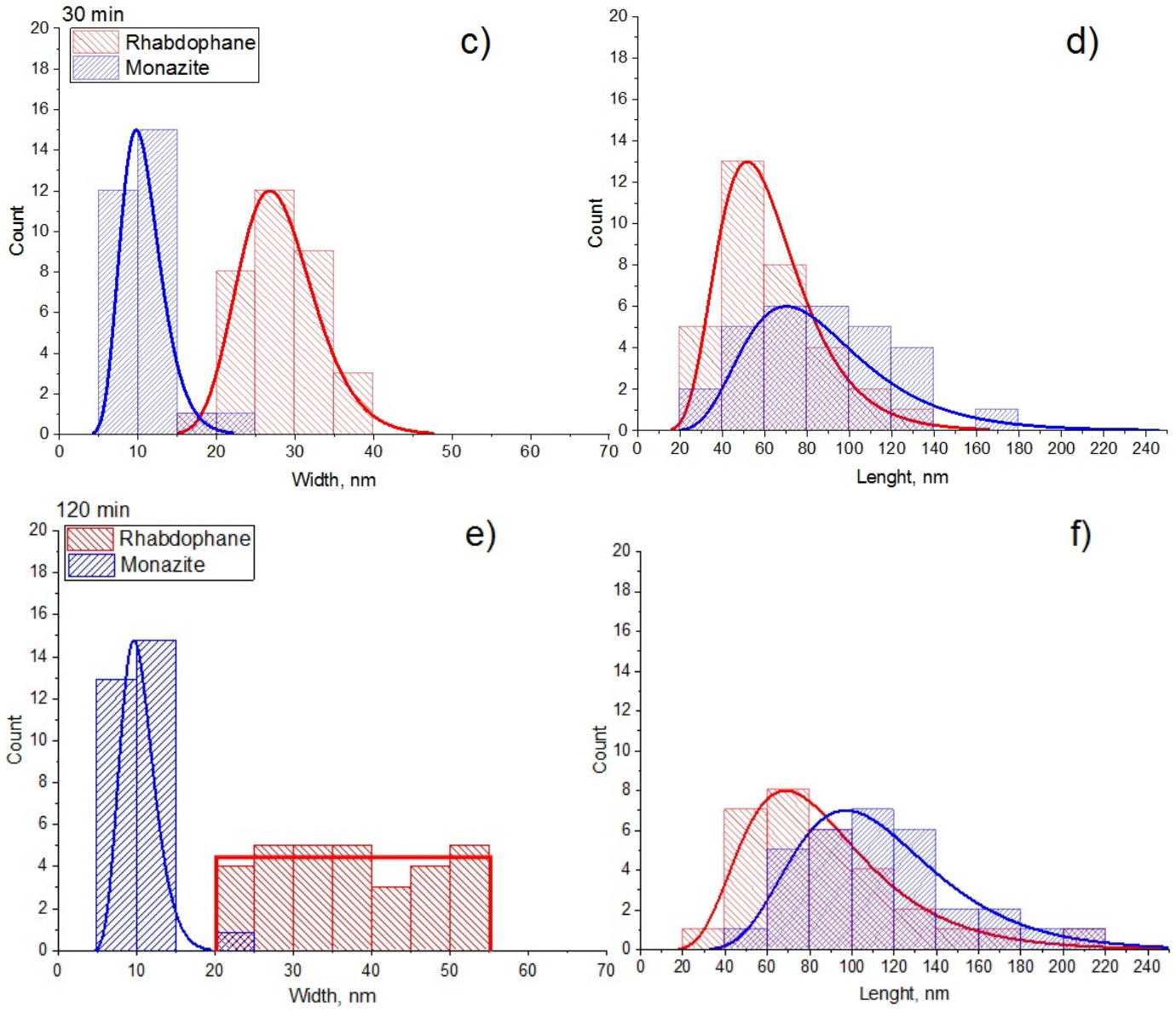

FIG. 7. Size distributions of thickness and length of rhabdophane and monazite nanoparticles according to TEM data. Samples after isothermal holding under hydrothermal conditions at $180{ }^{\circ} \mathrm{C}$ for various durations: (a,b) - 20 minutes; $(c, d)-30$ minutes; $(e, f)-120$ minutes 
The average thickness of nanorods with monazite structure does not change for the samples obtained after hydrothermal treatment at 30 and 120 minutes of isothermal holding, and is $\sim 12 \mathrm{~nm}$, which corresponds to the crystallite size at monazite phase, determined from X-ray diffraction data. That is, these nanoparticles can be considered mainly as monocrystalline. The average length of nanorods with monazite structure increases from $\sim 90$ to $\sim 120 \mathrm{~nm}$. Such length increase of nanorods of the phase with monazite structure correlates well with the fraction change of phases with monazite and rhabdophane structures in the system (Fig. 2); with a high degree of confidence can be associated with transfer of matter under hydrothermal conditions from the phase with rhabdophane structure to the phase with monazite structure while increase the isothermal holding time from 30 to $120 \mathrm{~min}$.

A comparative data analysis on changes in the phase ratio, elementary cell volumes, dimensional parameters of crystallites and particles with rhabdophane and monocyte structures during the microwave hydrothermal treatment process of precipitated lanthanum-yttrium orthophosphates, as well as direct observation of structural transformations in TEM micrographs (see, for example, Fig. 6d) allows us to represent the formation pattern of solid solutions in the system $0.53 \mathrm{LaPO}_{4}-0.47 \mathrm{YPO}_{4}-\left(n \mathrm{H}_{2} \mathrm{O}\right)$, as a series of the following processes:

1. a precipitation of lanthanum-yttrium orthophosphate with formation of nanocrystals with rhabdophane structure and amorphous phase;

2. crystallization of the amorphous phase under hydrothermal conditions with the formation of nanocrystals with rhabdophane structure and the formation of bimodal size distribution of monocrystalline (predominantly) nanoparticles;

3. the transformation of some nanocrystals with rhabdophane structure (the thinnest rod-like particles formed under hydrothermal conditions from amorphous phase) into monazite structure by degenerating one structure into another along the nanocrystal edges at the initial phase;

4. differentiation according to the composition of solid solutions of lanthanum-yttrium orthophosphates during structural transformation and stabilization as result of this two-phase state of the system;

5. the length increase (without changing the thickness) of nanoparticles of solid solutions of lanthanum-yttrium orthophosphates with monazite structure by transfer of matter under hydrothermal conditions from particles with rhabdophane structure;

6. the thickness increase of nanoparticles of solid solutions with rhabdophane structure by accretion of initially single-crystal nanoparticles;

7. the length increase of nanoparticles of lanthanum-yttrium orthophosphate with rhabdophane structure by mass transfer of matter under hydrothermal conditions.

\section{Conclusion}

As a result of studies, it has been shown that nanoparticles of phase with monazite structure having average crystallite size of 15-17 $\mathrm{nm}$ begin to form after 30 minutes of hydrothermal microwave-assisted treatment at $180{ }^{\circ} \mathrm{C}$ immediately after complete crystallization of amorphous phase in the system, the structural transition of the solid solution from phosphate lanthanum-yttrium with rhabdophane structure into monazite structure is based on degeneration of nanocrystals with rhabdophane structure along certain edges into monazite structure. The nanoparticle size increase (length of nanorods) with monazite structure after the stage of their formation occurs mainly due to matter transfer from nanoparticles having rhabdophane structure to nanoparticles having monazite structure, while thickness increase of rod-like particles with rhabdophane structure occurs due to their aggregation-accommodation coalescence. The system under considered conditions of hydrothermal treatment (temperature $-180{ }^{\circ} \mathrm{C}$, pressure $\sim 1-1.5 \mathrm{MPa}$, duration - up to $120 \mathrm{~min}$ ) remains two-phase due to composition differentiation of coexisting phases.

\section{Acknowledgments}

X-ray diffraction studies and elemental analysis of the samples performed using devices of the Engineering Center of the St. Petersburg State Technological Institute (Technical University).

Studies on transmission electron microscope were performed using equipment from the Federal Common Use Center "Materials Science and Diagnostics in Advanced Technologies" at the Ioffe Physical-Technical Institute of the Russian Academy of Sciences.

These studies were financially supported by the Russian Fundamental Research Fund (Project No. 18-29-12119).

\section{References}

[1] Du A., Wan C., Qu Z., Wu R., Pan W. Effects of texture on the thermal conductivity of the LaPO 4 monazite. Journal of the American Ceramic Society, 2010, 93, P. 2822-2827.

[2] Hikichi Y., Ota T., Daimon K., Hattori T., Mizuno M. Thermal, Mechanical, and Chemical Properties of Sintered Xenotime-Type RPO 4 (R = Y, Er, Yb, or Lu). Journal of the American Ceramic Society, 1998, 81, P. 2216-2218. 
[3] Ushakov S.V., Helean K.B., Navrotsky A., Boatner L.A. Thermochemistry of rare-earth orthophosphates. J. Mater. Res., 2001, 16(9), P. 26232633.

[4] Schlenz H., Heuser J., Neumann A., Schmitz S., Bosbach D. Monazite as a suitable actinide waste form. Crystalline Materials, 2013, 228(3), P. 113-123.

[5] Mezentseva L., Osipov A., Ugolkov V., Akatov A., Doil'nitsyn V., Maslennikova T., Yakovlev A. Synthesis and Thermal Behavior of Nanopowders in $\mathrm{LaPO}_{4}-\mathrm{YPO}_{4}\left(-\mathrm{H}_{2} \mathrm{O}\right), \mathrm{LaPO}_{4}-\mathrm{LuPO}_{4}\left(-\mathrm{H}_{2} \mathrm{O}\right)$ and $\mathrm{YPO}_{4}-\mathrm{ScPO}_{4}\left(-\mathrm{H}_{2} \mathrm{O}\right)$ Systems for Ceramic Matrices. J Nanomed. Res., 2017, 6(1), P. 00145.

[6] Gausse C., Szenknect S., Mesbah A., Clavier N., Neumeier S., Dacheux N. Dissolution kinetics of monazite LnPO 4 (Ln = La to Gd): A multiparametric study. Applied Geochemistry, 2018, 93, P. 81-93.

[7] Toro-González M., Dame A.N., Foster C. M., Millet L.J., Woodward J.D., Rojas J.V., Mirzadeh S., Davern S.M. Quantitative encapsulation and retention of ${ }^{227}$ Th and decay daughters in core-shell lanthanum phosphate nanoparticles. Nanoscale, 2020, 12, P. 9744-9755.

[8] Lenz C., Thorogood G., Aughterson R., Ionescu M., J. Gregg D., Davis J., Lumpkin, G. The quantification of radiation damage in orthophosphates using confocal $\mu$-luminescence spectroscopy of $\mathrm{Nd}^{3+}$. Frontiers in Chemistry, 2019, 7. Art.13.

[9] Osipov A.V., Mezentseva L.P., Drozdova I.A., Kuchaeva S.K., Ugolkov V.L., Gusarov V.V. Crystallization and thermal transformations in nanocrystals of the $\mathrm{YPO}_{4}-\mathrm{LuPO}_{4}-\mathrm{H}_{2} \mathrm{O}$ system. Glass. Phys. Chem., 2007, 33, P. 169-173.

[10] Osipov A.V., Mezentseva L.P., Drozdova I.A., Kuchaeva S.K., Ugolkov V.L., Gusarov V.V. Preparation and thermal transformations of nanocrystals in the $\mathrm{LaPO}_{4}-\mathrm{LuPO}_{4}-\mathrm{H}_{2} \mathrm{O}$ system. Glass. Phys. Chem, 2009, 35, P. 431-435.

[11] Ruigang W., Wei P., Jian C., Minghao F., Zhenzhu C., Yongming L. Synthesis and sintering of LaPO 4 powder and its application. Mater. Chem. Phys, 2003, 79(1), P. 30-36.

[12] Ferhi M., Horchani-Naifer K., Férid M. Combustion synthesis and luminescence properties of LaPO 4 : Eu (5\%). J. Rare Earths, 2009, 27(2), P. 182-186.

[13] Lai H., Bao A., Yang Y., et al. UV luminescence property of $\mathrm{YPO}_{4}: \mathrm{RE}\left(\mathrm{RE}=\mathrm{Ce}^{3+}, \mathrm{Tb}^{+}\right)$. J. Phys. Chem. C, 2007, 112(1), P. $282-286$.

[14] Pan W., Phillpot S.R., Wan C., Chernatynskiy A., Qu Z. Low thermal conductivity oxides. MRS Bull, 2012, 37(10), P. 917-922.

[15] Grechanovsky A.E., Eremin N.N., Urusov V.S. Radiation resistance of $\mathrm{LaPO}_{4}$ (monazite structure) and $\mathrm{YbPO}_{4}$ (zircon structure) from data of computer simulation. Phys Solid State, 2013, 55, P. 1929-1935.

[16] Terra O., Clavier N., Dacheux N., Podor R. Preparation and characterization of lanthanum-gadolinium monazites as ceramics for radioactive waste storage. New journal of Chemistry, 2003, 27(6), P. 957-967.

[17] Ohtaki K.K., Heravi N.J., Leadbetter J.W., Peter E.D. Morgan, Mecartney M.L. Extended solubility of Sr in LaPO 4 monazite. Solid State Ionics, 2016, 293, P. 44-50.

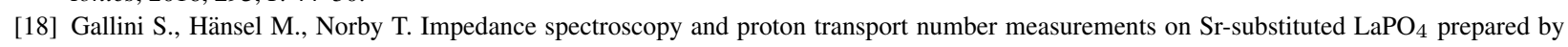
combustion synthesis. Solid State Ionics, 2003, 162-163, P. 167-173.

[19] Bryukhanova K.I., Nikiforova G.E., Gavrichev K.S. Synthesis and study of anhydrous lanthanide orthophosphate (Ln= La, Pr, Nd, Sm) nanowhiskers. Nanosystems: Physics, Chemistry, Mathematics, 2016, 7(3), P. 451-458.

[20] Larina L.L., Alexeeva O.V., Almjasheva O.V., Gusarov V.V., Kozlov S.S., Nikolskaia A.B., Vildanova M.F., Shevaleevskiy O.I. Very widebandgap nanostructured metal oxide materials for perovskite solar cells. Nanosystems: Physics, Chemistry, Mathematics, 2019, 10(1), P. 7075.

[21] Vildanova M.F., Nikolskaia A.B., Kozlov S.S., Karyagina O.K., Larina L.L., Shevaleevskiy O.I., Almjasheva O.V., Gusarov V.V. Nanostructured $\mathrm{ZrO}_{2}-\mathrm{Y}_{2} \mathrm{O}_{3}$-based system for perovskite solar cells. Doklady Physical Chemistry, 2019, 484(2), P. 36-38.

[22] Yorov Kh.E., Khodan A.N., Baranchikov A.E., Utochnikova V.V., Simonenko N.P., Beltiukov A.N., Petukhov D.I., Kanaev A., Ivanov V.K. Superhydrophobic and luminescent highly porous nanostructured alumina monoliths modified with tris(8-hydroxyquinolinato)aluminium. Microporous and Mesoporous Materials, 2020, 293, P. 109804.

[23] Sklyarova A., Popkov V.I., Pleshakov I.V., Matveev V.V., Stěpánková P.H., Chlan V. Peculiarities of ${ }^{57}$ Fe NMR Spectrum in Micro- and Nanocrystalline Europium Orthoferrites. Applied Magnetic Resonance, 2020.

[24] Popkov V.I., Bachina A.K., Valeeva A.A., Lobinsky A.A., Gerasimov E.Y., Rempel A.A. Synthesis, morphology and electrochemical properties of spherulite titania nanocrystals. Ceramics International, 2020, 46(15), P. 24483-24487.

[25] Kovalenko A.N., Tugova E.A. Thermodynamics and kinetics of non-autonomous phase formation in nanostructured materials with variable functional properties. Nanosystems: Physics, Chemistry, Mathematics, 2018, 9(5), P. 641-662.

[26] Roca A.G., Gutiérrez L., Gavilán H., Fortes Brollo M.E., Veintemillas-Verdaguer S., Puerto Morales M. Design strategies for shape-controlled magnetic iron oxide nanoparticles. Advanced Drug Delivery Reviews, 2019, 138, P. 68-104.

[27] Davis J.B., Marshall D.B., Morgan P.E.D. Monazite-Containing Oxide/Oxide Composites. J. Eur. Ceram. Soc, $2000,20(5)$, P. $583-587$.

[28] Arinicheva Y., Clavier N., Neumeier S., Podor R., Bukaemskiy A., Klinkenberg M., Roth G., Dacheux N., Bosbach D. Effect of powder morphology on sintering kinetics, microstructure and mechanical properties of monazite ceramics. J. Europ. Ceram. Soc., 2018, 38(1), P. 227234.

[29] Kenges K.M., Proskurina O.V., Danilovich D.P., Aldabergenov M.K., Gusarov V.V. Influence of the Conditions for Preparing LaPO 4 -Based Materials with Inclusions of the $\mathrm{LaP}_{3} \mathrm{O}_{9}$ Phase on Their Thermal and Mechanical Properties. Russ. J. App. Chem., 2018, 91(9), P. 1539-1548.

[30] Shijina K., Sankar S., Midhun M., Firozkhan M., Nair B.N., Warrier K.G., Hareesh U.N.S. Very low thermal conductivity in lanthanum phosphate-zirconia ceramic nanocomposites processed using a precipitation-peptization synthetic approach. New J. Chem., 2016, 40(6), P. 5333-5337.

[31] Zainurul A.Z., Rusop M., Abdullah S., Effect of annealing temperature on surface morphology of lanthanum phosphate $\left(\mathrm{LaPO}_{4}\right)$ nanostructures thin films. Advanced Materials Research, 2012, 626, P. 302-305.

[32] Ugolkov V.L., Mezentseva L.P., Osipov A.V., Popova V.F., Maslennikova T.P., Akatov A.A., Doil'nitsyn V.A. Synthesis of nanopowders and physicochemical properties of ceramic matrices of the $\mathrm{LaPO}_{4}-\mathrm{YPO}_{4}-\left(\mathrm{H}_{2} \mathrm{O}\right)$ and $\mathrm{LaPO}_{4}-\mathrm{HoPO}_{4}-\left(\mathrm{H}_{2} \mathrm{O}\right)$ systems. Rus. J. Appl. Chem., 2017, $90(1)$, P. 28-33.

[33] Maslennikova T.P., Osipov A.V., Mezentseva L.P., Drozdova I.A., Kuchaeva S.K., Ugolkov V.L., Gusarov V.V. Synthesis, Mutual Solubility, and Thermal Behavior of Nanocrystals in the $\mathrm{LaPO}_{4}-\mathrm{YPO}_{4}-\mathrm{H}_{2} \mathrm{O}$ System. Glass Physics and Chemistry, $2010,36(3), \mathrm{P} .351-357$.

[34] Mezentseva L., Osipov A., Ugolkov V., Kruchinina I., Popova V., Yakovlev A., Maslennikova T. Solid Solutions and Thermal Transformations in Nanosized $\mathrm{LaPO}_{4}-\mathrm{YPO}_{4}-\mathrm{H}_{2} \mathrm{O}$ and $\mathrm{LaPO}_{4}-\mathrm{LuPO}_{4}-\mathrm{H}_{2} \mathrm{O}$ Systems. J. Ceram. Sci. Tech., 2014, 05(03), P. $237-244$. 
[35] Mezentseva L.P., Kruchinina I.Yu., Osipov A.V., Kuchaeva S.K., Ugolkov V.L., Popova V.F., Pugachev K.E. Nanopowders of Orthophosphate $\mathrm{LaPO}_{4}-\mathrm{YPO}_{4}-\mathrm{H}_{2} \mathrm{O}$ System and Ceramics Based on Them. Glass Physics and Chemistry, 2014, 40(3), P. $356-361$.

[36] Wang R., Pan W., Chen J., Fang M., Meng J. Effect of $\mathrm{LaPO}_{4}$ content on the microstructure and machinability of $\mathrm{Al}_{2} \mathrm{O}_{3} / \mathrm{LaPO}_{4}$ composites. Mater Lett, 2002, 57(4), P. 822-827.

[37] Sankar S., Raj A.N., Jyothi C.K., Warrier K.G.K., Padmanabhan P.V.A. Room temperature synthesis of high temperature stable lanthanum phosphate-yttria nano composite. Mater Res Bull, 2012, 47(7), P. 1835-1837.

[38] Mezentseva L., Osipov A., Ugolkov V., Kruchinina I., Maslennikova T., Koptelova L. Sol-gel synthesis of precursors and preparation of ceramic composites based on $\mathrm{LaPO}_{4}$ with $\mathrm{Y}_{2} \mathrm{O}_{3}$ and $\mathrm{ZrO}_{2}$ additions. J. Sol-Gel Sci Technol, 2019, 92(2), P. $427-441$.

[39] Proskurina O.V., Sivtsov E.V., Enikeeva M.O., Sirotkin A.A., Abiev R.S., Gusarov V.V. Formation of rhabdophane-structured lanthanum orthophosphate nanoparticles in an impinging-jets microreactor and rheological properties of sols based on them. Nanosyst Physics, Chem Math, 2019, 10(2), P. 206-214.

[40] Wang S., Xu D., Guo Y., et al. Supercritical Hydrothermal Synthesis of Inorganic Nanomaterials. Supercritical Water Processing Technologies for Environment, Energy and Nanomaterial Applications, 2020, P. 117-147.

[41] Darr J.A., Zhang J., Makwana N.M., Weng X. Continuous Hydrothermal Synthesis of Inorganic Nanoparticles: Applications and Future Directions. Chem. Rev., 2017, 117(17), P. 11125-11238.

[42] Kenges K., Aldabergenov M., Proskurina O., Gusarov V. Hydrothermal synthesis of monostructured LaPO 4 : morphology and structure. Chem Bull Kazakh Natl Univ., 2018, 3(90), P. 12-19.

[43] Enikeeva M.O., Kenges K.M., Proskurina O.V., Danilovich D.P., Gusarov V.V. Influence of Hydrothermal Treatment Conditions on the Formation of Lanthanum Orthophosphate Nanoparticles of Monazite Structure. Russ. J. Appl. Chem., 2020, 93(4), P. 540-548.

[44] Patra C.R., Alexandra G., Patra S., et al. Microwave approach for the synthesis of rhabdophane-type lanthanide orthophosphate $($ Ln $=$ La, Ce, $\mathrm{Nd}, \mathrm{Sm}, \mathrm{Eu}, \mathrm{Gd}$ and Tb) nanorods under solvothermal conditions. New J. Chem., 2005, 29(5), P. 733-739.

[45] Ekthammathat N., Thongtem T., Phuruangrat A., Thongtem S. Microwave-assisted synthesis and characterisation of uniform LaPO 4 nanorods. J. Exp Nanosci, 2012, 7(6), P. 616-623.

[46] Zhang F.X., Wang J.W., Lang M., Zhang J.M., Ewing R.C., Boatner L.A. High-pressure phase transitions of ScPO 4 and YPO 4 . Phys. Rev. B - Condens Matter Mater Phys., Published online 2009, 80, P. 184114

[47] Ochiai A., Utsunomiya S. Crystal chemistry and stability of hydrated rare-earth phosphates formed at room temperature. Minerals, 2017, 7(5), P. 84.

[48] Mogilevsky P., Boakye E.E., HayAldered R.S. Solid Solubility and Thermal Expansion in a LaPO $4-\mathrm{YPO}_{4} \mathrm{System}$ Journal of the American Ceramic Society, 2007, 90(6), P. 1899-1907.

[49] Aldred A.T. Cell volumes of $\mathrm{APO}_{4}, \mathrm{AVO}_{4}$, and $\mathrm{ANbO}_{4}$ compounds, where A = Sc, Y, La-Lu. Acta Cryst., 1984, B40, P. 569-574.

[50] de Biasi R.S., Fernandes A.A.R., Oliveira J.C.S. Cell volumes of $\mathrm{LaPO}_{4}-\mathrm{CePO}_{4}$ solid solutions. J. Appl. Cryst., 1987, 20, P. 319-320.

[51] Dumler F.L., Skornyakova K.P., Shul'ga G.G. Lanthanum rhabdophane in the weathered mantle on limestones-a new type of rare earth mineralization. International Geology Review, 12(9), P. 1140-1145.

[52] Mooney R.C.L. Crystal structures of a series of rare earth phosphates. The Journal of Chemical Physics, 1948, 16, P. 1003-1004.

[53] Bowles J., Morgan D.J. The composition of rhabdophane. Mineralogical Magazine, 48(1), P. 146-148.

[54] Almjasheva O.V., Gusarov V.V. Metastable Clusters and Aggregative Nucleation Mechanism. Nanosystems: Physics, Chemistry, Mathematics, 2014, 5(3), P. 404-416. 